\title{
Acacia atrox (Fabaceae: Mimosoideae), a new rare species from the North Western Slopes, New South Wales
}

\author{
Phillip G. Kodela
}

\begin{abstract}
Kodela, P.G. (National Herbarium of New South Wales, Royal Botanic Gardens, Mrs Macquaries Rd, Sydney, NSW 2000, Australia) 2001. Acacia atrox (Fabaceae: Mimosoideae), a new rare species from the North Western Slopes, New South Wales. Telopea 9(2): 415-419. Acacia atrox, a new species, is described and illustrated. It does not appear to have any particularly close relatives, but may have some affinities with $A$. carneorum Maiden from which it is readily distinguished by its glabrous branchlets, pale-coloured flower-heads and especially by its phyllodes which are characteristically markedly splayed or dilated at their base. Acacia atrox is restricted to the Inverell region on the North Western Slopes of New South Wales and is provisionally listed as an endangered species, requiring planning and management for its conservation.
\end{abstract}

\section{Introduction}

During the year 2000 specimens of an unusual Acacia from the Inverell region with sessile, pungent-pointed phyllodes were sent to the National Herbarium of New South Wales by NSW Agriculture staff for identification. Perhaps the most distinctive feature of these plants was the base of their phyllodes which were conspicuously splayed, a most unusual (but not unique) character for an Acacia. The landholder of the property from where these specimens originated had concerns that this Acacia was spreading and could become a weed hazard for agricultural activities on his property. Some control methods had been practised in the past but the wattle prevailed and strategies for its management were being sought by the landholder and NSW Agriculture. It soon became apparent, however, that the Acacia in question had not been previously collected and was an undescribed species. Furthermore, it is known only from the type locality and has since been Provisionally Listed as an Endangered Species in the NSW Threatened Species Conservation Act, 1995.

\section{Taxonomy}

Acacia atrox Kodela sp. nov.

Frutex gregarius fortasse clonalis vulgo usque ad $2 \mathrm{~m}$ altus; phyllodia glabra quadrangularia vel teretia, sessilia, basi dilatata apice pungentia; capitula globularia, flavida, 17-25-flora, plerumque bina axi brevissimo insidentia; legumina ignota.

Type: New South Wales: North Western Slopes: Myall Creek Station, c. $18 \mathrm{~km} \mathrm{~S} \mathrm{of}$ Delungra, W of Inverell, W. Hawes, P. O'Keefe E J. Kewley NSW445997, 17 July 2000 (holo: NSW; iso: CANB, K, MEL, MO, PERTH).

Dense, much branched shrub normally $0.5-1.5(-2) \mathrm{m}$ high, oldest plants to $4 \mathrm{~m}$ high; main stem less than $10 \mathrm{~cm}$ diam. at breast height, sometimes twisted; spreading by suckering. Bark grey-brown, becoming dark grey and vertically fissured with age. 
Branchlets terete, pale green and slightly pruinose to pale yellowish green when dry, occasionally with a pinkish tinge when young, sometimes becoming encrusted with a brownish to blackish material with age, glabrous, with very low rounded ridges; axillary branchlets subtended by two caducous bracts (which usually leave fine scars on the stem when shed). Phyllodes sessile, patent to slightly inclined, \pm straight, \pm quadrangular in section (to \pm terete), with a yellow or pale-coloured vein at apex of each angle and a less prominent vein on the intervening faces $( \pm 8$-veined altogether, however, the intermediate veins are often incomplete not reaching the apex, obscure, wrinkle-like or not apparent, hence the phyllodes often appearing c. 4-veined), (1.5-) 2-4 (-4.5) cm long, 1-1.2 (-1.3) mm wide, rigid, light green (dry), glabrous (immature phyllodes with scattered, appressed, white-hyaline hairs), gradually tapered towards a pungent-pointed apex (the fine tip orange-brown and 1.5-3.5 $\mathrm{mm}$ long), abruptly broadened or splayed at base 2-6 $\mathrm{mm}$ wide (leaving an oval-obovate scar on branchlet when lost), with a small \pm circular gland on upper margin or vein near (or to $3 \mathrm{~mm}$ above) base and often a second minute gland c. $1 / 3-2 / 3$ from base; galls with a shape that is hakea fruit-like are commonly formed within some phyllodes. Inflorescences normally paired (often one of the peduncles missing) or sometimes single on a rudimentary raceme axis to $1 \mathrm{~mm}$ long (often appearing simple); peduncles $5-21 \mathrm{~mm}$ long, glabrous; bracts at base of peduncles deeply convex, \pm broadly ovate, often with a split or minor lobe/peak about midway below either side of the apex, to $2 \mathrm{~mm}$ long, sparsely ciliolate, often caducous; heads globular, 17-25-flowered, 5-7 mm diam. (dry), cream-coloured to pale yellow. Bracteoles \pm obovate to broadly spathulate, 0.9-1.1 mm long, ciliolate, with scattered minute hairs also on the outer surface of the claw especially along midline (which is often not central). Flowers 5-merous; calyx cupular, $0.8-1.2 \mathrm{~mm}$ long, dissected for $1 / 4(-1 / 3)$ or less, with minute hyaline-white hairs at base and often scattered on tube or concentrated along ribs, ciliolate along the obtuse to broadly rounded lobes; corolla dissected for $1 / 3-1 / 2$ or more, probably splitting towards base with age, the petals 1.5-1.9 mm long, 1-veined, glabrous or with inconspicuous, minute hairs or granules at apex mainly on margin, acute and often purplish in upper half; ovary glabrous to white-puberulous. Pods and seeds not seen. (Fig. 1).

Phenology: flowers recorded in May and July. No pod formation was observed during latter stages of flowering in mid-July 2000 (Hawes et al. 2000) and no pods were found in early November 2000 (T. Tame, pers. comm.). Although A. atrox has often been seen in flower in past years, pods have not been observed (W. Pollock, pers. comm.) and it is possible that they are rarely, if ever, produced.

Etymology: the specific epithet reflects the fierce or severe character of the plant created by the prominent pungent-pointed foliage.

Distribution: known only from a single collection site on Myall Creek Station, $18 \mathrm{~km}$ S of Delungra, west of Inverell, North Western Slopes, New South Wales.

Habitat: grows in deep clay soils, on basalt, on the upper slope and crest of a low hill, at head of a drainage depression, in a partly cleared paddock with Eucalyptus moluccana-E. albens Box woodland with a scattered understorey of Callitris glaucophylla and Notelaea microcarpa and a dense native grassy groundcover. Although the area has been used as native pasture for grazing stock, much of the woodland community is of mixed age and healthy condition with minor weed invasion (Hawes et al. 2000).

Conservation status: known only from the type locality. Provisionally listed under the informal name Acacia sp. 'Myall Creek' (Millar s.n. 25 May 2000) as an Endangered Species on Part 1 of Schedule 1 of the NSW Threatened Species Conservation Act, 1995. Acacia atrox warrants a 2E or 2V classification on the ROTAP list (Briggs \& Leigh 1996), depending on the degree of risk posed by present and future land uses in the area. 


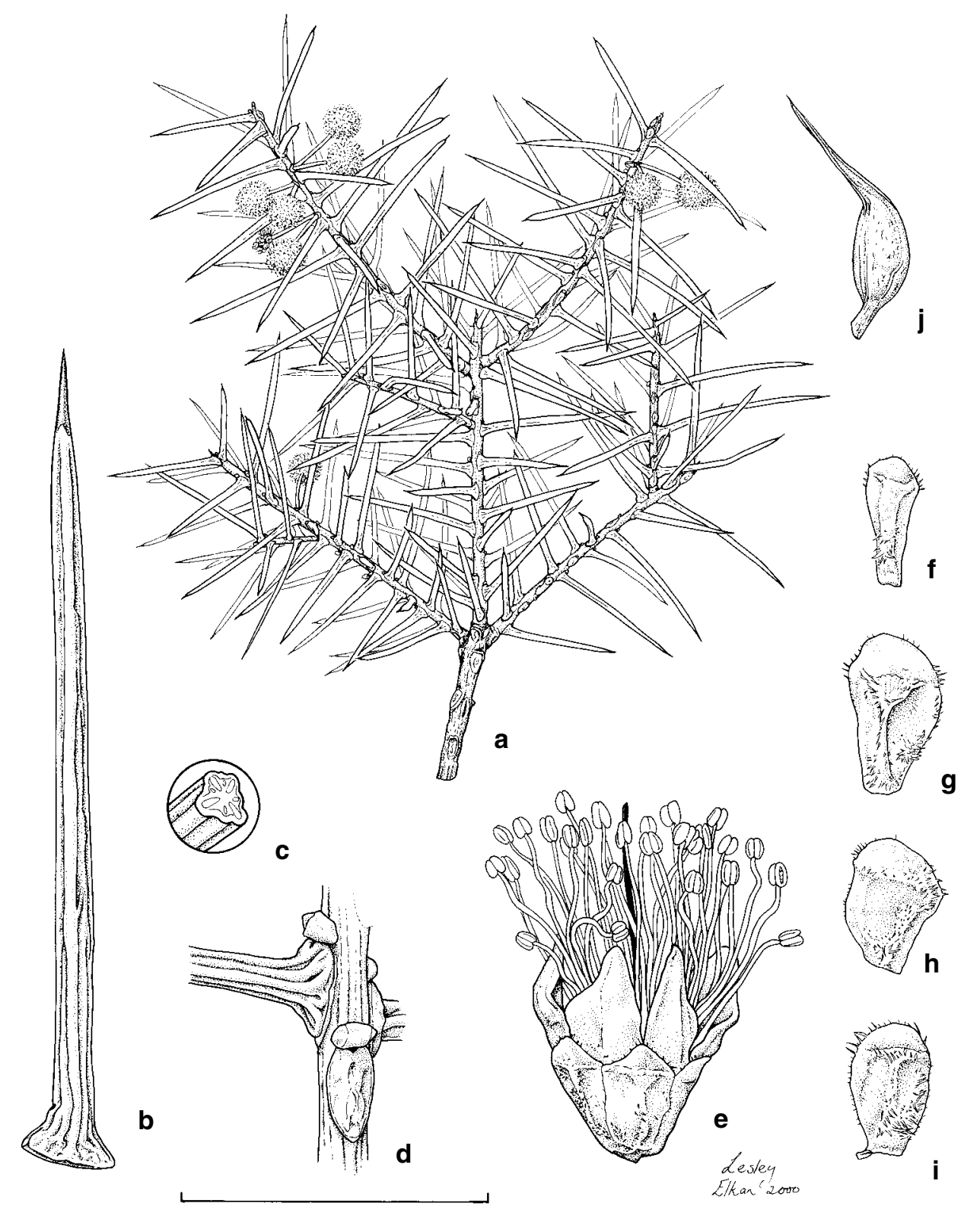

Fig. 1. Acacia atrox. a, branch with inflorescences; b, phyllode (Hawes et al. NSW445997); c, phyllode cross-section; $\mathbf{d}$, part of branchlet showing dilated phyllode base and scar left by a shed phyllode (Millar NSW441449); e, flower; $\mathbf{f}-\mathbf{i}$, bracteoles (Hawes et al. NSW445997); $\mathbf{j}$, gall formed within phyllode (Hawes et al. NSW445999). Scale bar: $\mathrm{a}, \mathrm{j}=4.2 \mathrm{~cm} ; \mathrm{b}, \mathrm{d}=1.2 \mathrm{~cm} ; \mathrm{c}=6 \mathrm{~mm} ; \mathrm{e}-\mathrm{i}=2.4 \mathrm{~mm}$. 
Other specimens examined: New South Wales: North Western Slopes: Myall Creek Station: W. Hawes, P. O'Keefe \& J. Kewley NSW445999-446002, 17 July 2000 (NSW); F. Millar NSW441449, 25 May 2000 (BRI, NSW, PERTH); K. Stevens NSW443828, 23 Feb 2000 (NSW); T. Tame 6285, 4 Nov 2000 (BRI, CANB, Hunter Region Botanic Gardens, MEL, NE, NSW, PERTH).

\section{Discussion}

Acacia atrox is distinguished by the markedly splayed or dilated base of its phyllodes. It does not appear to have any particularly close relatives, but may have some affinities with $A$. carneorum Maiden from central-eastern South Australia and the North and South Far Western Plains of New South Wales, which is superficially similar in its gregarious suckering habit, rigid, pungent phyllodes, globular flowerheads and united sepals. Acacia carneorum appears to produce few fruits, which may also be the case for $A$. atrox where pods have not been observed. Acacia carneorum mainly differs from $A$. atrox by not having splayed phyllode bases, and by having often thicker, 4-veined phyllodes (distinctly quadrangular in section), hairy branchlets and phyllodes (especially when young), simple inflorescences and yellow to bright yellow flower-heads.

The phyllodes of Acacia colletioides Benth. (which occurs in Western Australia, South Australia, New South Wales and Victoria) are superficially similar to those of A. atrox, however, they are strongly 8-veined, have raised stomata, are not splayed at the base and are inserted on distinct raised stem-projections; also the sepals are free in A. colletioides. Acacia pickardii Tindale (restricted in north-eastern South Australia and south-eastern Northern Territory) is superfically similar to A. atrox in that it has pungent phyllodes, spreads by suckering, produces hakea fruit-like galls in some phyllodes and appears to rarely produce fruit, but differs most obviously by the phyllodes being \pm erect, terete and obscurely 4-veined, the stipules conspicuously spinose, the inflorescences simple and the sepals free. Acacia pachypoda Maslin from Western Australia is superficially similar to A. atrox, especially because it also has pungent phyllodes with prominently dilated bases, however, the relationship between these two species is not close. Acacia pachypoda is a small shrub which differs significantly in having its short racemes subtended by conspicuous imbricate bracts which enclose the young heads, no bracteoles subtending the flowers, shorter peduncles, shorter phyllodes, and more. In the absence of $A$. atrox pods and biochemical or genetic (DNA) studies it is difficult to further assess possible relationships of this unusual species.

Hawes et al. (2000) estimated a population of 50 000-100 000 individual plants (or more correctly, stems, if clonal) of $A$. atrox in an area of approximately 10 ha., and T. Tame (pers. comm.) estimated 20000 plants in an area of approximately 2 ha. However, many of the plants, if not the whole population, could be clonal since younger plants appear to be suckering from existing roots and the plants are morphologically very uniform (Hawes et al. 2000; T. Tame, pers. comm.). According to Hawes et al. (2000), vegetative reproduction and apparent poor seed production in this species is also indicated by the absence of any individuals further down the local catchment.

There is a history of habitat disturbance, including the 'thinning' of vegetation, grazing (cattle until very recently), pasture improvement (most recently 2 years ago) and stick raking (4 years ago) (Hawes et al. 2000). These activities may well have promoted the apparent expansion of $A$. atrox in recent years through disturbance of the soil and surface roots stimulating extensive suckering (Hawes et al. 2000). There is the possibility that the area might be burned with the aim of controlling the spread 
of $A$. atrox. However, the impact of fire on $A$. atrox is unknown and might have the opposite effect. The situation calls for a monitoring program and studies aimed to assist the landholder and authorities maintain a balance between productive farming and conservation of this endangered species.

Further field surveys in the region should be carried out to determine if there are other populations of $A$. atrox and possible threats to the species. More information is required on its biology and ecology, including reproduction strategies and life cycles. This could be assisted by propagation ex situ, which may also be necessary to help protect the species. Specimens with pods remain to be found and would provide further insights on the species biology and possible related species. Furthermore, flavonoid studies on the wood may provide results that help suggest relationships. There is also the possibility for phylogenetic and population genetic studies, as well as entomological studies on the galls. The known population of $A$. atrox and its habitat should be managed to help protect this very rare and possibly ancient or relic species.

\section{Acknowledgments}

Thankyou to Mr Fred Millar, Myall Creek Station, for bringing attention to this new rare species and for his observations, as well as for allowing access and field studies on his property. I am very grateful to Wendy Hawes, Paul O'Keefe and James Kewley of the NSW Department of Land and Water Conservation, Inverell, for their specimen collections and report. Many of the details in this paper are based on findings from their thorough site inspection. Comments on A. atrox and/or the manuscript were provided by Terry Tame (Hunter Region Botanic Gardens \& NSW), Bruce Maslin (PERTH), NSW Agriculture, Mr K. Stevens, Wayne Pollock and Doug Benson (NSW). John Benson (NSW) assisted with liaising with collectors and government departments. Dr Peter Wilson (NSW) kindly provided the Latin description. Lesley Elkan (NSW) is gratefully acknowledged for drawing the illustration.

\section{References}

Briggs, J.D. \& Leigh, J.H. (1996) Rare or threatened Australian plants, 1995 revised edition. (CSIRO: Collingwood).

Hawes, W., O'Keefe, P. \& Kewley, J. (2000) Acacia sp. 'Myall Creek' (Millar s.n. 25 May 2000): site inspection and sample collection. (Department of Land and Water Conservation: Inverell). Unpublished report. 